\title{
WOMANIST CONSCIOUSNESS: MAGGIE LENA WALKER AND THE INDEPENDENT ORDER OF SAINT LUKE
}

\section{ELSA BARKLEY BROWN}

In the first decades of the twentieth century Maggie Lena Walker repeatedly challenged her contemporaries to "make history as $\mathrm{Ne}$ gro women." Yet she and her colleagues in the Independent Order of Saint Luke, like most black and other women of color, have been virtually invisible in women's history and women's studies. Although recent books and articles have begun to redress this, ${ }^{1}$ the years of exclusion have had an impact more significant than just the invisibility of black women, for the exclusion of black women has meant that the concepts, perspectives, methods, and pedagogies of

My appreciation is expressed to Mary Kelley, Deborah K. King, Lillian Jones, and the participants in the Community and Social Movements research group of the 1986 Summer Research Institute on Race and Gender, Center for Research on Women, Memphis State University, for their comments on an earlier draft of this article.

The recent proliferation of works in black women's history and black women's studies makes a complete bibliographical reference prohibitive. For a sample of some of the growing literature on black women's consciousness, see Evelyn Brooks, "The Feminist Theology of the Black Baptist Church, 1880-1900," in Class, Race, and Sex: The Dynamics of Control, ed. Amy Swerdlow and Hanna Lessinger (Boston: G. K. Hall, 1983), 31-59; Hazel V. Carby, Reconstructing Womanhood: The Emergence of the Afro-American Woman Novelist (New York: Oxford University Press, 1987); Elizabeth Clark-Lewis, " 'This Work Had a' End': The Transition from Live-

[Signs: Journal of Women in Culture and Society 1989, vol. 14, no. 3]

1989 by The University of Chicago. All rights reserved. 0097-9740/89/1403-0002\$01.00 
women's history and women's studies have been developed without consideration of the experiences of black women. As a result many of the recent explorations in black women's history have attempted to place black women inside feminist perspectives which, by design, have omitted their experiences. Nowhere is this exclusion more apparent than in the process of defining women's issues and women's struggle. Because they have been created outside the experiences of black women, the definitions used in women's history and women's studies assume the separability of women's struggle and race struggle. Such arguments recognize the possibility that black women may have both women's concerns and race concerns, but they insist upon delimiting each. They allow, belatedly, black women to make history as women or as Negroes but not as "Negro women." What they fail to consider is that women's issues may be race issues, and race issues may be women's issues. 2

Rosalyn Terborg-Penn, in "Discontented Black Feminists: Prelude and Postscript to the Passage of the Nineteenth Amendment," an essay on the 1920s black women's movement, of which Walker was a part, persuasively discusses the continuing discrimination in the U.S. women's movement and the focus of black women on -uplifting the downtrodden of the race or. . representing people

In to Day Work," Southern Women: The Intersection of Race, Class, and Gender Working Paper no. 2 (Memphis, Tenn.: Memphis State University, Center for Research on Women, 1985); Patricia Hill Collins, 'The Social Construction of Black Feminist Thought, ${ }^{-}$Signs:Journal of Women in Culture and Society 14, no. 4 (Summer 1989), forthcoming; Cheryl Townsend Gilkes, 'Together and in Harness': Women's Traditions in the Sanctified Church, ${ }^{-}$Signs 10, no. 4 (Summer 1985): 67899; Deborah Gray White, Ar'n't I a Woman? Female Slaves in the Plantation South (New York: Norton, 1985). Also note: Sage: A Scholarly Journal on Black. Women, now in its fifth year, has published issues that focus on education, health, work, mother-daughter relationships, and creative artists.

${ }^{2}$ On a contemporary political level, this disassociation of gender concerns from race concerns was dramatically expressed in the 1985 United Nations Decade for Women conference held in Nairobi, Kenya, where the official U.S. delegation, including representatives of major white women's organizations but not one representative of a black women's organization, insisted upon not having the proceedings become bogged down with race and national issues such as apartheid so that it could concentrate on birth control and other "women's" issues. Delegates operating from such a perspective were unable to see African, Asian, and Latin American women who argued for discussion of national political issues as anything other than the tools of men, unfortunate victims unable to discern true women's and feminist struggles. For a discussion of the ways in which these issues were reflected in the Kenya conference, see Ros Young, "Report from Nairobi: The UN Decade for Women Forum, ${ }^{-}$Race and Class 27, no. 2 (Autumn 1985): 67-71; and the entire issue of African Women Rising, vol. 2, no. 1 (Winter-Spring 1986). 
of color throughout the world." Subsequently she argues for the "unique nature of feminism among Afro-American women." The editors of Decades of Discontent: The Women's Movement, 1920 1940, the 1983 collection on post-Nineteenth Amendment feminism, however, introduce Terborg-Penn's article by mistakenly concluding that these black women, disillusioned and frustrated by racism in the women's movement, turned from women's issues to race issues. Using a framework that does not conceive of "racial uplift, fighting segregation and mob violence" and "contending with poverty" as women's issues, Lois Scharf and Joan Jensen succumb to the tendency to assume that black women's lives can be neatly subdivided, that while we are both black and female, we occupy those roles sequentially, as if one cannot have the two simultaneously in one's consciousness of being. ${ }^{3}$ Such a framework assumes a fragmentation of black women's existence that defies reality.

Scharf and Jensen's conclusion is certainly one that the white feminists of the 1920s and 1930s, who occupy most of the book, would have endorsed. When southern black women, denied the right to register to vote, sought help from the National Woman's Party, these white feminists rejected their petitions, arguing that this was a race concern and not a women's concern. Were they not, after all, being denied the vote not because of their sex but because of their race? 4

Black women like Walker who devoted their energies to securing universal suffrage, including that of black men, are not widely recognized as female suffragists because they did not separate their struggle for the women's vote from their struggle for the black vote. This tendency to establish false dichotomies, precluding the pos-

\footnotetext{
${ }^{3}$ See Rosalyn Terborg-Penn, "Discontented Black Feminists: Prelude and Postscript to the Passage of the Nineteenth Amendment," 261-78; Lois Scharf and Joan M. Jensen, "Introduction, ${ }^{-}$9-10, both in Decades of Discontent: The Women's Movement, 1920-1940, ed. Lois Scharf and Joan M. Jensen (Westport, Conn.: Greenwood, 1983).

${ }^{4}$ Terborg-Penn, 267. A contemporary example of this type of dichotomous analysis is seen in much of the discussion of the feminization of poverty. Drawing commonalities between the experiences of black and white women, such discussions generally leave the impression that poverty was not a "feminine - problem before white women in increasing numbers were recognized as impoverished. Presumably, before that black women's poverty was considered a result of race; now it is more often considered a result of gender. Linda Burnham has effectively addressed the incompleteness of such analyses, suggesting that they ignore "class, race, and sex as simultaneously operative social factors ${ }^{-}$in black women's lives ("Has Poverty Been Feminized in Black America?" Black Scholar 16, no. 2 [March/April 1985]: 14-24 (emphasis mind).
} 
sibility that for many racism and sexism are experienced simultaneously, leads to discussions of liberation movements and women's movements as separate entities.

Quite clearly, what many women of color at the United Nations Decade for Women conference held in Nairobi, Kenya, in 1985, along with many other activists and scholars, have argued in recent years is the impossibility of separating the two and the necessity of understanding the convergence of women's issues, race/nationalist issues, and class issues in women's consciousnesses. ${ }^{5}$ That understanding is in part hampered by the prevailing terminology: feminism places a priority on women; nationalism or race consciousness, a priority on race. It is the need to overcome the limitations of terminology that has led many black women to adopt the term -womanist.- Both Alice Walker and Chikwenye Okonjo Ogunyemi have defined womanism as a consciousness that incorporates racial, cultural, sexual, national, economic, and political considerations. ${ }^{6}$ As Ogunyemi explains, - black womanism is a philosophy" that concerns itself both with sexual equality in the black community and - with the world power structure that subjugates ${ }^{-}$both

${ }^{5}$ See, e.g., Parita Trivedi, "A Study of 'Sheroes; Third World Book Review 1, no. 2 (1984): 71-72; Angela Davis, Women, Race, and Class (New York: Random House, 1981); Nawal el Saadawi, The Hidden Face of Eve: Women in the Arab World, trans. Sherif Hetata (Boston: Beacon, 1982); Jenny Bourne, "Towards an Anti-Racist Feminism," Race and Class 25, no. 1 (Summer 1983): 1-22; Bonnie Thornton Dill, "Race, Class, and Gender: Prospects for an All-Inclusive Sisterhood," Feminist Studies 9, no. 1 (Spring 1983): 131-50; Evelyn Nakano Glenn, Issei, Nisei, War Bride: Three Generations of Japanese American Women in Domestic Service (Philadelphia: Temple University Press, 1986); Audre Lorde, Sister/Outsider: Essays and Speeches (Trumansburg, N.Y.: Crossing Press, 1984); Barbara Smith, "Some Home Truths on the Contemporary Black Feminist Movement," Black Scholar 16, no. 2 (March/April 1985): 4-13; Asoka Bandarage, Toward International Feminism: The Dialectics of Sex, Race and Class (London: Zed Press, forthcoming). For a typology of black women's multiple consciousness, see Deborah K. King, "Race, Class, and Gender Salience in Black Women's Feminist Consciousness" (paper presented at American Sociological Association annual meeting, Section on Racial and Ethnic Minorities, New York, August 1986).

${ }^{6}$ Alice Walker's oft-quoted definition is in In Search of Our Mothers' Gardens: Womanist Prose (New York: Harcourt, Brace, Jovanovich, 1983), xi-xii: "Womanist. 1. . . Responsible. In Charge. Serious. 2. .. . Appreciates. . . women's strength.. . . Committed to survival and wholeness of entire people, male and female. Not a separatist, except periodically, for health. Traditionally universalist. . . . Traditionally capable. . . . 3. . . Loves struggle. Loves the Folk. Loves herself. Regardless. 4. Womanist is to feminist as purple is to lavender." Cheryl Townsend Gilkes's annotation of Alice Walker's definition ("Women, Religion, and Tradition: A Womanist Perspective" [paper presented in workshop at Summer Research Institute on Race and Gender, Center for Research on Women, Memphis State University, June 1986]) has been particularly important to my understanding of this term. 
blacks and women. "Its ideal is for black unity where every black person has a modicum of power and so can be a 'brother' or a 'sister' or a 'father' or a 'mother' to the other. ... [Ilts aim is the dynamism of wholeness and self-healing.-7

Walker's and Ogunyemi's terminology may be new, but their ideas are not. In fact, many black women at various points in history had a clear understanding that race issues and women's issues were inextricably linked, that one could not separate women's struggle from race struggle. It was because of this understanding that they refused to disconnect themselves from either movement. They instead insisted on inclusion in both movements in a manner that recognized the interconnection between race and sex, and they did so even if they had to battle their white sisters and their black brothers to achieve it. Certainly the lives and work of women such as Anna Julia Cooper, Mary Church Terrell, and Fannie Barrier Williams inform us of this. Cooper, an early Africanamerican womanist, addressed the holistic nature of the struggle in her address to the World's Congress of Representative Women:

Let woman's claim be as broad in the concrete as in the abstract. We take our stand on the solidarity of humanity, the oneness of life, and the unnaturalness and injustice of all special favoritisms, whether of sex, race, country, or condition. If one link of the chain be broken, the chain is broken. ... We want, then, as toilers for the universal triumph of justice and human rights, to go to our homes from this Congress, demanding an entrance not through a gateway for ourselves, our race, our sex, or our sect, but a grand highway for humanity. The colored woman feels that woman's cause is one and universal; and that not till ... race, color, sex, and condition are seen as the accidents, and not the substance of life; .. . not till then is woman's lesson taught and woman's cause won-not the white woman's, nor the black woman's, nor the red woman's, but the cause of every man and of every woman who has writhed silently under a mighty wrong. Woman's wrongs are thus indissolubly linked with all undefended woe, and the acquirement of her "rights" will mean the final triumph of all right over inight, the supremacy of the moral forces of reason, and justice, and love in the government of the nations of earth.8

\footnotetext{
${ }^{7}$ Chikwenye Okonjo Ogunyemi, "Womanism: The Dynamics of the Contemporary Black Female Novel in English, ${ }^{-}$Signs 11, no. 1 (Autumn 1985): 63-80.

${ }^{8}$ May Wright Sewall, ed., World's Congress of Representative Women (Chicago, 1893), 715, quoted in Bert James Loewenberg and Ruth Bogin, eds., Black. Women in Nineteenth-Century American Life: Their Words, Their Thoughts, Their Feelings
} 
One of those who most clearly articulated womanist consciousness was Maggie Lena Walker. Walker (1867-1934) was born and educated in Richmond, Virginia, graduating from Colored Normal School in 1883 . During her school years she assisted her widowed mother in her work as a washerwoman and cared for her younger brother. Following graduation she taught in the city's public schools and took courses in accounting and sales. Required to stop teaching when she married Armstead Walker, a contractor, her coursework had well prepared her to join several other black women in founding an insurance company, the Woman's Union. Meanwhile, Walker, who had joined the Independent Order of Saint Luke at the age of fourteen, rose through the ranks to hold several important positions in the order and, in 1895, to organize the juvenile branch of the order. In addition to her Saint Luke activities, Walker was a founder or leading supporter of the Richmond Council of Colored Women, the Virginia State Federation of Colored Women, the National Association of Wage Earners, the International Council of Women of the Darker Races, the National Training School for Girls, and the Virginia Industrial School for Colored Girls. She also helped direct the National Association for the Advancement of Colored People, the Richmond Urban League, and the Negro Organization Society of Virginia.9

(University Park: Pennsylvania State University Press, 1976), 330-31 (emphasis mine). See also Anna Julia Cooper, A Voice from the South: By a Black Woman of the South (Xenia, Ohio: Aldine, 1892), esp. "Part First."

${ }^{9}$ Although there exists no scholarly biography of Walker, information is available in several sources. See Wendell P. Dabney, Maggie L. Walker and The 1.0. of Saint Luke: The Woman and Her Work (Cincinnati: Dabney, 1927); Sadie Iola Daniel, Women Builders (Washington, D.C.: Associated Publishers, 1931), 28-52; Sadie Daniel St. Clair, "Maggie Lena Walker," in Notable American Women, 1607-1960 (Cambridge, Mass.: Harvard University Press, Belknap, 1971), 530-31; Elsa Barkley Brown, "Maggie Lena Walker and the Saint Luke Women" (paper presented at the Association for the Study of Afro-American Life and History 69th annual conference, Washington, D.C., October 1984), and" 'Not Alone to Build This Pile of Brick': The Role of Women in the Richmond, Virginia, Black Community, 1890-1930" (paper presented at the Midcontinental and North Central American Studies Association joint conference, University of Iowa, April 1983); Lily Hammond, In the V anguard of a Race (New York: Council of Women for Home Missions and Missionary Education Movement of the United States and Canada, 1922), 108-18; A. B. Caldwell, ed., Virginia Edition, vol. 5 of History of the American Negro (Atlanta: A. B. Caldwell, 1921), 9-11; Rayford Logan, "Maggie Lena Walker," in Dictionary of American Negro Biography, ed. Rayford W. Logan and Michael R. Winston (New York: Norton, 1982), 626-27; Gertrude W. Marlowe, "Maggie Lena Walker: African-American Women, Business, and Community Development" (paper presented at Berkshire Conference on the History of Women, Wellesley, Mass., June 21, 1987); Kim Q. Boyd,

" 'An Actress Born, a Diplomat Bred'; Maggie L. Walker, Race Woman" (M.A. thesis, Howard University, 1987); Sallie Chandler, "Maggie Lena Walker (1867-1934): An 
Walker is probably best known today as the first woman bank president in the United States. She founded the Saint Luke Penny Savings Bank in Richmond, Virginia, in 1903. Before her death in 1934 she oversaw the reorganization of this financial institution as the present-day Consolidated Bank and Trust Company, the oldest continuously existing black-owned and black-run bank in the country. The bank, like most of Walker's activities, was the outgrowth of the Independent Order of Saint Luke, which she served as Right Worthy Grand Secretary for thirty-five years.

The Independent Order of Saint Luke was one of the larger and more successful of the many thousands of mutual benefit societies that have developed throughout Africanamerican communities since the eighteenth century. These societies combined insurance functions with economic development and social and political activities. As such they were important loci of community self-help and racial solidarity. Unlike the Knights of Pythias and its female auxiliary, the Courts of Calanthe, societies like the Independent Order of Saint Luke had a nonexclusionary membership policy; any man, woman, or child could join. Thus men and women from all occupational segments, professional/managerial, entrepreneurial, and working-class, came together in the order. The Independent Order of Saint Luke was a mass-based organization that played a key role in the political, economic, and social development of its members and of the community as a whole. ${ }^{\circ}$

Founded in Maryland in 1867 by Mary Prout, the Independent Order of Saint Luke began as a women's sickness and death mutual benefit association. By the 1880s it had admitted men and had expanded to New York and Virginia. At the 1899 annual meeting William M. T. Forrester, who had served as Grand Secretary since 1869 , refused to accept reappointment, stating that the order was in decline, having only 1,080 members in fifty-seven councils, $\$ 31.61$ in the treasury, and $\$ 400.00$ in outstanding debts. Maggie Lena

\footnotetext{
Abstract of Her Life and Activities," 1975 Oral History Files, Virginia Union University Library, Richmond, Va., 1975; Maggie Lena Walker Papers, Maggie L. Walker National Historic Site, Richmond, Va. (hereafter cited as MLW Papers). Fortunately, much of Walker's history will soon be available; the Maggie L. Walker Biography Project, funded by the National Park Service under the direction of Gertrude W. Marlowe, anthropology department, Howard University, is completing a full-scale biography of Walker.

${ }^{10}$ Noting the mass base of mutual benefit societies such as the Independent Order of Saint Luke, August Meier has suggested that the activities of these organizations "reflect the thinking of the inarticulate majority better than any other organizations or the statement of editors and other publicists" (Negro Thought in America, 1880 1915: Racial Ideologies in the Age of Booker T. Washington [Ann Arbor: University of Michigan Press, 19631, 130).
} 
Walker took over the duties of Grand Worthy Secretary at one-third of the position's previous salary."

According to Walker, her "first work was to draw around me women." ${ }^{12}$ In fact, after the executive board elections in 1901, six of the nine members were women: Walker, Patsie K. Anderson, Frances Cox, Abigail Dawley, Lillian H. Payne, and Ella 0. Waller.13 Under their leadership the order and its affiliates flourished. The order's ventures included a juvenile department, an educational loan fund for young people, a department store, and a weekly newspaper. Growing to include over 100,000 members in 2,010 councils and circles in twenty-eight states, the order demonstrated a special commitment to expanding the economic opportunities within the black community, especially those for women.

It is important to take into account Walker's acknowledgment of her female colleagues. Most of what we know about the Order of Saint Luke highlights Walker because she was the leader and spokeswoman and therefore the most visible figure. She was able, however, to function in that role and to accomplish all that she did not merely because of her own strengths and skills, considerable though they were, but also because she operated from the strength of the Saint Luke collective as a whole and from the special strengths and talents of the inner core of the Saint Luke women in particular. Deborah Gray White, in her work on women during slavery, underscores the importance of black women's networks in an earlier time period: - Strength had to be cultivated. It came no more naturally to them than to anyone. . . . If they seemed exceptionally strong it was partly because they often functioned in groups and derived strength from numbers. ... [T] hey inevitably developed some appreciation of one another's skills and talents. This intimacy enabled them to establish the criteria with which to rank and order themselves. - It was this same kind of sisterhood that was Walker's base, her support, her strength, and her source of wisdom and direction."

" 50th Anniversary-Golden Jubilee Historical Report of the R. W. G. Council I. O. St. Luke, 1867-1917 (Richmond, Va.: Everett Waddey, 1917), 5-6, 20 (hereafter cited as 50 th Anniversary).

${ }^{12}$ Maggie L. Walker, "Diary," March 6, 1928, MLW Papers. My thanks to Sylvester Putman, superintendent, Richmond National Battlefield Park, and Celia Jackson Suggs, site historian, Maggie L. Walker National Historic Site, for facilitating my access to these unprocessed papers.

1350 th Anniversary, 26.

"White (n. 1 above), 119-41. Although I use the term "sisterhood" here to refer to this female network, sisterhood for black women, including M. L. Walker, meant (and means) not only this special bond among black women but also the ties amongst all kin/community. 
The women of Saint Luke expanded the role of women in the community to the political sphere through their leadership in the 1904 streetcar boycott and through the St. Luke Herald's pronouncements against segregation, lynching, and lack of equal educational opportunities for black children. Walker spearheaded the local struggle for women's suffrage and the voter registration campaigns after the passage of the Nineteenth Amendment. In the 1920 elections in Richmond, fully 80 percent of the eligible black voters were women. The increased black political strength represented by the female voters gave incentive to the growing movement for independent black political action and led to the formation of the Virginia Lily-Black Republican Party. Walker ran on this ticket for state superintendent of public instruction in 1921.' ${ }^{\prime}$ Thus Walker and many other of the Saint Luke women were role models for other black women in their community activities as well as their occupations.

Undergirding all of their work was a belief in the possibilities inherent in the collective struggle of black women in particular and of the black community in general. Walker argued that the only way in which black women would be able "to avoid the traps and snares of life" would be to "band themselves together, organize, ... put their mites together, put their hands and their brains together and make work and business for themselves." 16

The idea of collective economic development was not a new idea for these women, many of whom were instrumental in estab-

\footnotetext{
${ }^{15}$ Of 260,000 black Virginians over the age of twenty-one in 1920, less than 20,000 were eligible to vote in that year's elections. Poll taxes and literacy tests disfranchised many; white Democratic election officials turned many others away from the polls; still others had given up their efforts to vote, realizing that even if they successfully cast their ballots, they were playing in "a political game which they stood no chance of winning" (Andrew Buni, The Negro in Virginia Politics, 19021965 [Charlottesville: University of Virginia Press, 1967], 77-88). The high proportion of female voters resulted from whites' successful efforts to disfranchise the majority of black male voters, as well as the enthusiasm of women to exercise this new right; see, e.g., Richmond News-Leader (August-October 1920); Richmond Times-Dispatch (September-October, 1920). Rosalyn Terborg-Penn (n. 3 above, 275) reports a similarly high percentage of black female voters in 1920s Baltimore. In Richmond, however, black women soon found themselves faced with the same obstacles to political rights as confronted black men. Independent black political parties developed in several southern states where the lily-white Republican faction had successfully purged blacks from leadership positions in that party; see, e.g., George C. Wright, "Black Political Insurgency in Louisville, Kentucky: The Lincoln Independent Party of 1921," Journal of Negro History 68 (Winter 1983): 8-23.

${ }^{16}$ M. L. Walker, "Addresses," 1909, MLW Papers, cited in Celia Jackson Suggs, "Maggie Lena Walker," TRUTH: Newsletter of the Association of Black. Women Historians 7 (Fall 1985): 6.
} 
lishing the Woman's Union, a female insurance company founded in 1898. Its motto was The Hand That Rocks the Cradle Rules the World.' ${ }^{7}$ But unlike nineteenth-century white women's rendering of that expression to signify the limitation of woman's influence to that which she had by virtue of rearing her sons, the idea as these women conceived it transcended the separation of private and public spheres and spoke to the idea that women, while not abandoning their roles as wives and mothers, could also move into economic and political activities in ways that would support rather than conflict with family and community. Women did not have to choose between the two spheres; in fact, they necessarily had to occupy both. Indeed, these women's use of this phrase speaks to their understanding of the totality of the task that lay ahead of them as black women. It negates, for black women at least, the public/private dichotomy.

Saint Luke women built on tradition. A well-organized set of institutions maintained community in Richmond: mutual benefit societies, interwoven with extended families and churches, built a network of supportive relations. ${ }^{18}$ The families, churches, and societies were all based on similar ideas of collective consciousness and collective responsibility. Thus, they served to extend and reaffirm notions of family throughout the black community. Not only in their houses but also in their meeting halls and places of worship, they were brothers and sisters caring for each other. The institutionalization of this notion of family cemented the community. Community/family members recognized that this had to be maintained from generation to generation; this was in part the function of the juvenile branches of the mutual benefit associations. The statement of purpose of the Children's Rosebud Fountains, Grand Fountain United Order of True Reformers, clearly articulated this:

Teaching them . . . to assist each other in sickness, sorrow and afflictions and in the struggles of life; teaching them that one's happiness greatly depends upon the others.... Teach them to live united. ... The children of different families will know how to ... talk, plot and plan for one another's peace and happiness in the journey of life.

\footnotetext{
${ }^{17}$ Four of the women elected to the 1901 Saint Luke executive board were board members of the Woman's Union, which had offices in Saint Luke's Hall; see advertisements in Richmond Planet (August 1898-January 3, 1903).

${ }^{18}$ Some of the societies had only women members, including some that were exclusively for the mutual assistance of single mothers. For an excellent discussion of the ties among the societies, families, and churches in Richmond, see Peter J. Rachleff, Black Labor in the South: Richmond, Virginia, 1865-1890 (Philadelphia: Temple University Press, 1984).
} 
Teach them to. . . bear each other's burdens. . . to so bind and tie their love and affections together that one's sorrow may be the other's sorrow, one's distress be the other's distress, one's penny the other's penny."

Through the Penny Savings Bank the Saint Luke women were able to affirm and cement the existing mutual assistance network among black women and within the black community by providing an institutionalized structure for these activities. The bank recognized the meager resources of the black community, particularly black women. In fact, its establishment as a penny savings bank is an indication of that. Many of its earliest and strongest supporters were washerwomen, one of whom was Maggie Walker's mother. And the bank continued throughout Walker's leadership to exercise a special commitment to "the small depositor." 20

In her efforts Walker, like the other Saint Luke women, was guided by a clearly understood and shared perspective concerning the relationship of black women to black men, to the black community, and to the larger society. This was a perspective that acknowledged individual powerlessness in the face of racism and sexism and that argued that black women, because of their condition and status, had a right-indeed, according to Walker, a special duty and incentive- to organize. She argued, "Who is so helpless as the Negro woman? Who is so circumscribed and hemmed in, in the race of life, in the struggle for bread, meat and clothing as the Negro woman?-2'

In addition, her perspective contended that organizational activity and the resultant expanded opportunities for black women

\footnotetext{
${ }^{19}$ W. P. Burrell and D. E. Johnson, Sr., Twenty-Five Years History of the Grand Fountain of the United Order of True Reformers, 1881-1905 (Richmond, Va.: Grand Fountain, United Order of True Reformers, 1909), 76-77.

${ }_{20}$ Saint Luke Penny Savings Bank records: Receipts and Disbursements, 19031909; Minutes, Executive Committee, 1913; Cashier's Correspondence Book, 1913; Minutes, Board of Trustees, 1913-1915, Consolidated Bank and Trust Company, Richmond, Va.; Cleveland Plain Dealer (June 28, 1914), in Peabody Clipping File, Collis P. Huntington Library, Hampton Institute, Hampton, Va. (hereafter cited as Peabody Clipping File), no. 88, vol. 1. See also Works Progress Administration, The Negro in Virginia (New York: Hastings House, 1940), 299.

2. This analysis owes much to Cheryl Townsend Gilkes's work on black women, particularly her - Black Women's Work as Deviance: Social Sources of Racial Antagonism within Contemporary Feminism, ${ }^{-}$working paper no. 66 (Wellesley, Mass.: Wellesley College Center for Research on Women, 1979), and " 'Holding Back the Ocean with a Broom': Black Women and Community Work, ${ }^{-}$in The Black. Woman, ed. LaFrances Rodgers-Rose (Beverly Hills, Calif.: Sage, 1980). Excerpt from speech given by M. L. Walker at 1901 annual Saint Luke convention, 50th Anniversary (n. 11 above), 23.
} 
were not detrimental to the home, the community, black men, or the race. Furthermore, she insisted that organization and expansion of women's roles economically and politically were essential ingredients without which the community, the race, and even black men could not achieve their full potential. The way in which Walker described black women's relationship to society, combined with the collective activities in which she engaged, give us some insight into her understanding of the relationship between women's struggle and race struggle.

Walker was determined to expand opportunities for black women. In fulfilling this aim she challenged not only the larger society's notions of the proper place of blacks but also those in her community who held a limited notion of women's proper role. Particularly in light of the increasing necessity to defend the integrity and morality of the race, a "great number of men" and women in Virginia and elsewhere believed that women's clubs, movements -looking to the final exercise of suffrage by women, ${ }^{-}$and organizations of black professional and business women would lead to "the decadence of home life." 22 Women involved in these activities were often regarded as -pullbacks, rather than home builders." ${ }^{23}$ Maggie Walker countered these arguments, stressing the need for women's organizations, saying, "Men should not be so pessimistic and down on women's clubs. They don't seek to destroy the home or disgrace the race!" ${ }^{24}$ In fact, the Richmond Council of Colored Women, of

\footnotetext{
22 The prevailing turn-of-the-century stereotype of black women emphasized promiscuity and immorality; these ideas were given prominence in a number of publications, including newspapers, periodicals, philanthropic foundation reports, and popular literature. The attacks by various segments of the white community on the morality of black women and the race at the turn of the century are discussed in Beverly Guy-Sheftall, " 'Daughters of Sorrow': Attitudes toward Black Women, 1880-1920" (Ph.D. diss., Emory University, 1984), 62-86; Darlene Clark Hine, "Lifting the Veil, Shattering the Silence: Black Women's History in Slavery and Freedom," in The State of Afro-American History: Past, Present, and Future, ed. Darlene Clark Hine (Baton Rouge: Louisiana State University Press, 1986), 223-49, esp. 234-38; Willi Coleman, "Black Women and Segregated Public Transportation: Ninety Years of Resistance," TRUTH: Newsletter of the Association of Black Women Historians 8, no. 2 (1986): 3-10, esp. 7-8; and Paula Giddings, When and Where I Enter: The Impact of Black Women on Race and Sex in America (New York: William Morrow, 1984), 82-86. Maggie Walker called attention to these verbal attacks on Negro womanhood in her speech, "Beniah's Valour: An Address for Men Only," Saint Luke Hall, March 1,1906, MLW Papers (n. 9 above). It was in part the desire to defend black women and uplift the race that initiated the formation of the National Federation of Black Women's Clubs.

${ }^{23}$ Charles F. McLaurin, "State Federation of Colored Women" (n.p., November 10,1908), Peabody Clipping File, no. 231, vol. I.

${ }^{24}$ Chandler (n. 9 above), 10-11.
} 
which she was founder and president, and many other women's organizations worked to elevate the entire black community, and this, she believed, was the proper province of women.

In 1908 two Richmond men, Daniel Webster Davis and Giles Jackson, published The Industrial History of the Negro Race of the United States, which became a textbook for black children throughout the state. The chapter on women acknowledged the economic and social achievements of black women but concluded that "the Negro Race Needs Housekeepers. . . wives who stay at home, being supported by their husbands, and then they can spend time in the training of their children. ${ }^{-25}$ Maggie Walker responded practically to those who held such ideas: ${ }^{-}$The bold fact remains that there are more women in the world than men; . .. if each and every woman in the land was allotted a man to marry her, work for her, support her, and keep her at home, there would still be an army of women left uncared for, unprovided for, and who would be compelled to fight life's battles alone, and without the companionship of man.-26 Even regarding those women who did marry, she contended, "The old doctrine that a man marries a woman to support her is pretty nearly thread-bare to-day. ${ }^{-}$Only a few black men were able to fully support their families on their earnings alone. Thus many married women worked, - not for name, not for glory and honor-but for bread, and for [their] babies.-27

The reality was that black women who did go to work outside the home found themselves in a helpless position. "How many occupations have Negro Women?" asked Walker. "Let us count them: Negro women are domestic menials, teachers and church builders.And even the first two of these, she feared, were in danger. As Walker perceived it, the expansion of opportunities for white women did not mean a corresponding expansion for black women; instead, this trend might actually lead to an even greater limitation on the economic possibilities for black women. She pointed to the fact that white women's entry into the tobacco factories of the city had "dri-

\footnotetext{
${ }^{25}$ Daniel Webster Davis and Giles Jackson, The Industrial History of the Negro Race of the United States (Richmond: Virginia Press, 1908), 133. Similar attitudes expressed in the Virginia Baptist in 1894 had aroused the ire of the leading figures in the national women's club movement. The Baptist had been particularly concerned that women, in exceeding their proper place in the church, were losing their "womanliness" and that "the exercise of the right of suffrage would be a deplorable climax to these transgressions"; see discussion of the Baptist in Women's Era 1, no. 6 (September 1894): 8.

${ }^{25}$ M. L. Walker, "Speech to Federation of Colored Women's Clubs," Hampton, Va., July 14, 1912, MLW Papers (n. 9 above).

${ }^{27}$ M. L. Walker, "Speech to the Negro Young People's Christian and Educational Congress," Convention Hall, Washington, D.C., August 5, 1906, MLW Papers.
} 
"en the Negro woman out," and she, like many of her sisters throughout the country, feared that a similar trend was beginning even in domestic work. 28

In fact, these economic realities led members of the Order of Saint Luke to discuss the development of manufacturing operations as a means of giving employment and therefore "a chance in the race of life" to "the young Negro woman." ${ }^{29}$ In 1902 Walker described herself as "consumed with the desire to hear the whistle on our factory and see our women by the hundreds coming to work." ${ }^{30}$ It was this same concern for the economic status of black women that led Walker and other Saint Luke women to affiliate with the National Association of Wage Earners (NAWE), a women's organization that sought to pool the energies and resources of housewives, professionals, and managerial, domestic, and industrial workers to protect and expand the economic position of black women. The NAWE argued that it was vital that all black women be able to support themselves.' Drawing on traditional stereotypes in the same breath with which she defied them, Walker contended that it was in the self-interest of black men to unite themselves with these efforts to secure decent employment for black women: "Every dollar a woman makes, some man gets the direct benefit of same. Every woman was by Divine Providence created for some man; not for some man to marry, take home and support, but for the purpose of using her powers, ability, health and strength, to forward the financial ... success of the partnership into which she may go, if she will. . . [W] [Wat stronger combination could ever God make - than the partnership of a business man and a business woman."32

\footnotetext{
${ }^{28}$ Quotations are from M. L. Walker, "Speech to the Federation of Colored Women's Clubs." These ideas, however, were a central theme in Walker's speeches and were repeated throughout the years. See, e.g., "Speech to the Negro Young People's Christian and Educational Congress" and "Beniah's Valour: An Address for Men Only" (n. 22 above). See also the St. Luke Herald's first editorial, "Our Mission" (March 29, 1902), reprinted in 50th Anniversary (n. 11 above), 26.

${ }^{29}$ Excerpt from speech given by M. L. Walker at 1901 annual Saint Luke convention, 50th Anniversary, 23.

30 See "Our Mission" (n. 28 above).

${ }^{31}$ The NAWE, having as its motto "Support Thyself-Work," aimed at making "the colored woman a factor in the labor world." Much of its work was premised upon the belief that white women were developing an interest in domestic science and other "Negro occupations" to such an extent that the prospects for work for young black women were becoming seriously endangered. They believed also that when white women entered the fields of housework, cooking, and the like, these jobs would be classified as professions. It therefore was necessary for black women to become professionally trained in even domestic work in order to compete. Container 308, Nannie Helen Burroughs Papers, Manuscript Division, Library of Congress.

${ }^{32}$ M. L. Walker, "Speech to Federation of Colored Women's Clubs" (n. 26 above).
} 
By implication, whatever black women as a whole were able to achieve would directly benefit black men. In Walker's analysis family is a reciprocal metaphor for community: family is community and community is family. But this is more than rhetorical style. Her discussions of relationship networks suggest that the entire community was one's family. Thus Walker's references to husbands and wives reflected equally her understandings of male/female relationships in the community as a whole and of those relationships within the household. Just as all family members' resources were needed for the family to be well and strong, so they were needed for a healthy community/family.

In the process of developing means of expanding economic opportunities in the community, however, Walker and the Saint Luke women also confronted white Richmond's notions of the proper place of blacks. While whites found a bank headed by a "Negress" an interesting curiosity, ${ }^{33}$ they were less receptive to other business enterprises. In 1905 twenty-two black women from the Independent Order of Saint Luke collectively formed a department store aimed at providing quality goods at more affordable prices than those available in stores outside the black community, as well as a place where black women could earn a living and get a business education. The Saint Luke Emporium employed fifteen women as salesclerks. While this may seem an insignificant number in comparison to the thousands of black women working outside the home, in the context of the occupational structure of Richmond these women constituted a significant percentage of the white-collar and skilled working-class women in the community. In 1900 less than 1 percent of the employed black women in the city were either clerical or skilled workers. That number had quadrupled by 1910 , when 222 of the more than 13,000 employed black women listed their occupations as typists, stenographers, bookkeepers, salesclerks, and the like. However, by 1930 there had been a reduction in the numbers of black women employed in clerical and sales positions. This underscores the fact that black secretaries and clerks were entirely dependent on the financial stability of black businesses and in this regard the Independent Order of Saint Luke was especially important. With its fifty-five clerks in the home office, over one-third of the black female clerical workers in Richmond in the 1920s worked for this order. The quality of the work experience was significantly better for these women as compared to those em-

33 See, e.g., "Negress Banker Says If Men Can, Women Can," Columbus Journal (September 16, 1909), Peabody Clipping File (n. 20 above), no. 231, vol. 7; see also Chandler (n. 9 above), 32. 
ployed as laborers in the tobacco factories or as servants in private homes. They worked in healthier, less stressful environments and, being employed by blacks, they also escaped the racism prevalent in most black women's workplaces. Additionally, the salaries of these clerical workers were often better than those paid even to black professional women, that is, teachers. While one teacher, Ethel Thompson Overby, was receiving eighteen dollars a month as a teacher and working her way up to the top of the scale at forty dollars, a number of black women were finding good working conditions and a fifty-dollar-per-month paycheck as clerks in the office of the Independent Order of Saint Luke. Nevertheless, black women in Richmond, as elsewhere, overwhelmingly remained employed in domestic service in the years 1890-1930.34

Located on East Broad Street, Richmond's main business thoroughfare, the Saint Luke Emporium met stiff opposition from white merchants. When the intention to establish the department store was first announced, attempts were made to buy the property at a price several thousand dollars higher than that which the Order of Saint Luke had originally paid. When that did not succeed, an offer of ten thousand dollars cash was made to the order if it would not start the emporium. Once it opened, efforts were made to hinder the store's operations. A white Retail Dealers' Association was formed for the purpose of crushing this business as well as other - Negro merchants who are objectionable. . . because they compete with and get a few dollars which would otherwise go to the white merchant. ${ }^{-}$Notices were sent to wholesale merchants in the city warning them not to sell to the emporium at the risk of losing all business from any of the white merchants. Letters were also sent to wholesale houses in New York City with the same warning. These letters charged that the emporium was underselling the white merchants of Richmond. Clearly, then, the white businessmen of Rich-

In 1900, 83.8 percent of employed black women worked in domestic and personal service; in 1930, 76.5 percent. U.S. Bureau of the Census, Twelfth Census of the United States Taken in the Year 1900, Population Part 1 (Washington, D.C.: Census Office, 1901), Thirteenth Census of the United States Taken in the Year 1910, vol. 4: Population 1910 - Occupation Statistics (Washington, D.C.: Government Printing Office, 1914), 595, and Fifteenth Census of the United States: Population, vol. 4: Occupations, by States (Washington, D.C.: Government Printing Office, 1933); Benjamin Brawley, Negro Builders and Heroes (Chapel Hill: University of North Carolina Press, 1937), 267 - 72; U.S. Bureau of the Census, Fourteenth Census of the United States Taken in the Year 1920, vol. 4: Population 1920-Occupations (Washington, D.C.: Government Printing Office, 1923); Ethel Thompson Overby, "It's Better to Light a Candle than to Curse the Darkness": The Autobiographical Notes of Ethel Thompson Overby (1975), copy in Virginia Historical Society, Richmond. 
mond found the emporium and these black women a threat; if it was successful, the store could lead to a surge of black merchants competing with white merchants and thus decrease the black patronage at white stores. The white merchants' efforts were ultimately successful: the obstacles they put in the way of the emporium, in addition to the lack of full support from the black community itself, resulted in the department store's going out of business seven years after its founding. ${ }^{35}$ Though its existence was short-lived and its demise mirrors many of the problems that black businesses faced from both within and without their community, the effort demonstrated the commitment of the Order of Saint Luke to provide needed services for the community and needed opportunities for black women.

Maggie Walker's appeals for support of the emporium show quite clearly the way in which her notions of race, of womanhood, and of community fused. Approximately one year after the opening of the emporium, Walker called for a mass gathering of men in the community to talk, in part, about support for the business. Her speech, "Beniah's Valour; An Address for Men Only," opened with an assessment of white businessmen's and officials' continuing oppression of the black community. In her fine rhetorical style she queried her audience. "Hasn't it crept into your minds that we are being more and more oppressed each day that we live? Hasn't it yet come to you, that we are being oppressed by the passage of laws which not only have for their object the degradation of Negro manhood and Negro womanhood, but also the destruction of all kinds of Negro enterprises?" Then, drawing upon the biblical allegory of Beniah and the lion, she warned, "There is a lion terrorizing us, preying upon us, and upon every business effort which we put forth. The name of this insatiable lion is PREJUDICE. . . The white press, the white pulpit, the white business associations, the legislatureall ... the lion with whom we contend daily . . . in Broad Street, Main Street and in every business street of Richmond. Even now ... that lion is seeking some new plan of attack."36

Thus, she contended, the vital question facing their community was how to kill the lion. And in her analysis, "the only way to kill

\footnotetext{
35 The business, which opened the Monday before Easter, 1905, officially closed in January 1912. Information on the emporium is found in 50th Anniversary (n. 11 above), 55, 76-77; New Y ork Age, March 16, 1905, Peabody Clipping File, no. 88, vol. 1, "Maggie Lena Walker Scrapbook," MLW Papers (n. 9 above); Daniels (n. 9 above), 41. The most detailed description of the opposition to the emporium is in M. L. Walker, "Beniah's Valour: An Address for Men Only- (n. 22 above), quote is from this speech.

${ }^{36}$ M. L. Walker, "Beniah's Valour: An Address for Men Only.-
} 
the Lion is to stop feeding it." The irony was that the black community drained itself of resources, money, influence, and patronage to feed its predator. ${ }^{37}$ As she had many times previously, Walker questioned the fact that while the white community oppressed the black, "the Negro ... carries to their bank every dollar he can get his hands upon and then goes back the next day, borrows and then pays the white man to lend him his own money." ${ }^{38}$ So, too, black people patronized stores and other businesses in which white women were, in increasing numbers, being hired as salesclerks and secretaries while black women were increasingly without employment and the black community as a whole was losing resources, skills, and finances. ${ }^{39}$ Walker considered such behavior racially destructive and believed it necessary to break those ties that kept "the Negro ... so wedded to those who oppress him." $4^{\circ}$ The drain on the resources of the black community could be halted by a concentration on the development of a self-sufficient black community. But to achieve this would require the talents of the entire community/ family. It was therefore essential that black women's work in the community be - something more tangible than elegant papers, beautifully framed resolutions and pretty speeches.- Rather, "the exercising of every talent that God had given them- was required in the effort to "raise ... the race to higher planes of living.

The Saint Luke women were part of the Negro Independence Movement that captured a large segment of Richmond society at the turn of the century. Disillusioned by the increasing prejudice and discrimination in this period, which one historian has described as the nadir in U.S. race relations, black residents of Richmond nevertheless held on to their belief in a community that they could collectively sustain. ${ }^{42}$ As they witnessed a steady erosion of their civil and political rights, however, they were aware that there was much operating against them. In Richmond, as elsewhere, a system of race and class oppression including segregation, disfranchisement, relegation to the lowest rungs of the occupational strata, and enforcement of racial subordination through intimidation was fully in place by the early twentieth century. In Richmond between 1885 and 1915 all blacks were removed from the city council; the only

\footnotetext{
${ }^{37}$ Ibid.

${ }^{38}$ Chandler (n. 9 above), 30.

${ }^{39}$ M. L. Walker, "Beniah's Valour: An Address for Men Only.-

${ }^{40}$ Chandler, 30.

${ }^{41}$ New York Age (June 22, 1909), Peabody Clipping File, no. 231, vol. 1.

${ }^{42}$ Rayford W. Logan, The Betrayal of the Negro from Rutherford B. Hayes to Woodrow Wilson (New York: Collier, 1965; originally published in 1954 as The Negro in American Life and Thought: The Nadir).
} 
predominantly black political district, Jackson Ward, was gerrymandered out of existence; the state constitutional convention disfranchised the majority of black Virginians; first the railroads and streetcars, and later the jails, juries, and neighborhoods were segregated; black principals were removed from the public schools and the right of blacks to teach was questioned; the state legislature decided to substitute white for black control of Virginia Normal and College and to strike - and College" from both name and function; and numerous other restrictions were imposed. As attorney J. Thomas Hewin noted, he and his fellow black Richmonders occupied "a peculiar position in the body politics":

He [the Negro] is not wanted in politics, because his presence in official positions renders him obnoxious to his former masters and their descendants. He is not wanted in the industrial world as a trained handicraftsman, because he would be brought into competition with his white brother. He is not wanted in city positions, because positions of that kind are always saved for the wardheeling politicians. He is not wanted in State and Federal offices, because there is an unwritten law that a Negro shall not hold an office. He is not wanted on the Bench as a judge, because he would have to pass upon the white man's case also. Nor is he wanted on public conveyances, because here his presence is obnoxious to white people:"

Assessing the climate of the surrounding society in 1904, John Mitchell, Jr., editor of the Richmond Planet, concluded, "This is the beginning of the age of conservatism."'" The growing movement within the community for racial self-determination urged blacks to depend upon themselves and their community rather than upon whites: to depend upon their own inner strengths, to build their own institutions, and thereby to mitigate the ways in which their lives were determined by the white forces arrayed against them. Race pride, self-help, racial cooperation, and economic development were central to their thinking about their community and to the ways in which they went about building their own internal

43 J. Thomas Hewin, "Is the Criminal Negro Justly Dealt with in the Courts of the South?" in Twentieth Century Negro Literature, or a Cyclopedia of Thought on the Vital Topics Relating to the American Negro, ed. D. W. Culp (Toronto: J. L. Nichols, 1902), 110-11.

" Richmond Planet (April 30, 1904). 
support system in order to be better able to struggle within the majority system.

The Saint Luke women argued that the development of the community could not be achieved by men alone, or by men on behalf of women. Only a strong and unified community made up of both women and men could wield the power necessary to allow black people to shape their own lives. Therefore, only when women were able to exercise their full strength would the community be at its full strength, they argued. Only when the community was at its full strength would they be able to create their own conditions, conditions that would allow men as well as women to move out of their structural isolation at the bottom of the labor market and to overcome their political impotence in the larger society. The Saint Luke women argued that it was therefore in the self-interest of black men and of the community as a whole to support expanded opportunities for women.

Their arguments redefined not only the roles of women but also the roles and notions of manhood. A strong "race man" traditionally meant one who stood up fearlessly in defense of the race. In her -Address for Men" Walker argued that one could not defend the race unless one defended black women. Appealing to black men's notions of themselves as the protectors of black womanhood, she asked on behalf of all her sisters for their "FRIENDSHIP, ... LOVE, ... SYMPATHY, .. PROTECTION, and ... ADVICE": "I am asking you, men of Richmond, ... to record [yourselves] as ... the strong race men of our city.... I am asking each man in this audience to go forth from this building, determined to do valiant deeds for the Negro Women of Richmond." ${ }^{45}$ And how might they offer their friendship, love, and protection; how might they do valiant deeds for Negro womanhood? By supporting the efforts of black women to exercise every talent; ${ }^{46}$ by "let[ting] woman choose her own vocation, just as man does his"; ${ }^{47}$ by supporting the efforts then underway to provide increased opportunities - economic, political, and social—-for black women." Once again she drew upon tradi-

\footnotetext{
${ }^{45}$ M. L. Walker, "Beniah's Valour: An Address for Men Only" (n. 22 above).

${ }^{46}$ New York Age (June 22, 1909), Peabody Clipping File, no. 231, vol. 1.

${ }^{47}$ M. L. Walker, "Speech to the Federation of Colored Women's Clubs" (n. 26 above).

${ }^{48}$ M. L. Walker, "Beniah's Valour: An Address for Men Only." This appeal for support of increased opportunities for black women permeated all of Walker's speeches. In her last speeches in 1934 she continued her appeal for support of race enterprises (newspaper clipping [n.p., n.d.], "Maggie Laura Walker Scrapbook," MLW Papers [n. 9 abovel). Maggie Laura Walker is Walker's granddaughter.
} 
tional notions of the relationship between men and women at the same time that she countered those very notions. Black men could play the role of protector and defender of womanhood by protecting and defending and aiding women's assault on the barriers generally imposed on women. ${ }^{49}$ Only in this way could they really defend the race. Strong race consciousness and strong support of equality for black women were inseparable. Maggie Walker and the other Saint Luke women therefore came to argue that an expanded role for black women within the black community itself was an essential step in the community's fight to overcome the limitations imposed upon the community by the larger society. Race men were therefore defined not just by their actions on behalf of black rights but by their actions on behalf of women's rights. The two were inseparable.

This was a collective effort in which Walker believed black men and black women should be equally engaged. Therefore, even in creating a woman's organization, she and her Saint Luke associates found it essential to create space within the structure for men as well. Unlike many of the fraternal orders that were male or female only, the Order of Saint Luke welcomed both genders as members and as employees. Although the office force was all female, men were employed in the printing department, in field work, and in the bank. Principal offices within the order were open to men and women. Ten of the thirty directors of the emporium were male; eight of the nineteen trustees of the order were male. The Saint Luke women thus strove to create an equalitarian organization, with men neither dominant nor auxiliary. Their vision of the order was a reflection of their vision for their community. In the 1913 Saint Luke Thanksgiving Day celebration of the order, Maggie Walker "thank[ed] God that this is a woman's organization, broad enough, liberal enough, and unselfish enough to accord equal rights and equal opportunity to men. $-5^{\circ}$

Only such a community could become self-sustaining, self-sufficient, and independent, could enable its members to live lives unhampered by the machinations of the larger society, and could raise children who could envision a different world in which to live

${ }^{49}$ W. E. B. DuBois, who explored extensively the connection between race struggle and women's struggle in "The Damnation of Women," also challenged men's traditional roles: "The present mincing horror of a free womanhood must pass if we are ever to be rid of the bestiality of a free manhood; not by guarding the weak in weakness do we gain strength, but by making weakness free and strong ${ }^{-}$(emphasis mine; Darkwater, Voices from within the Veil [New York: Harcourt, Brace, \& Howe, 1920], 165).

M. L. Walker, "Saint Luke Thanksgiving Day Speech," City Auditorium, March 23, 1913, MLW Papers (n. 9 above). 
and then could go about creating it. The women in the Order of Saint Luke sought to carve a sphere for themselves where they could practically apply their belief in their community and in the potential that black men and women working together could achieve, and they sought to infuse that belief into all of black Richmond and to transmit it to the next generation.

The Saint Luke women challenged notions in the black community about the proper role of women; they challenged notions in the white community about the proper place of blacks. They expanded their roles in ways that enabled them to maintain traditional values of family/community and at the same time move into new spheres and relationships with each other and with the men in their lives. To the larger white society they demonstrated what black men and women in community could achieve. This testified to the idea that women's struggle and race struggle were not two separate phenomena but one indivisible whole. - First by practice and then by precept"' Maggie Lena Walker and the Saint Luke women demonstrated in their own day the power of black women discovering their own strengths and sharing them with the whole community. ${ }^{52}$ They provide for us today a model of womanist praxis.

Womanism challenges the distinction between theory and action. Too often we have assumed that theory is to be found only in carefully articulated position statements. Courses on feminist theory are woefully lacking on anything other than white, Western, middle-class perspectives; feminist scholars would argue that this is due to the difficulty in locating any but contemporary black feminist thought. Though I have discussed Maggie Lena Walker's public statements, the clearest articulation of her theoretical perspective lies in the organization she helped to create and in her own activities. Her theory and her action are not distinct and separable parts of some whole; they are often synonymous, and it is only through her actions that we clearly hear her theory. The same is true for the lives of many other black women who had limited time and resources and maintained a holistic view of life and struggle.

More important, Maggie Lena Walker's womanism challenges the dichotomous thinking that underlies much feminist theory and writing. Most feminist theory poses opposites in exclusionary and hostile ways: one is black and female, and these are contradictory/ problematical statuses. This either/or approach classifies phenom-

\footnotetext{
${ }^{51}$ M. L. Walker, "Address—Virginia Day Third Street Bethel AME Church," January 29, 1933, MLW Papers.

${ }^{52}$ Ogunyemi (n. 7 above; $72-73$ ) takes this idea from Stephen Henderson's analysis of the role of the blues and blues women in the Africanamerican community.
} 
ena in such a way that "everything falls into one category or another, but cannot belong to more than one category at the same time."53 It is precisely this kind of thinking that makes it difficult to see race, sex, and class as forming one consciousness and the resistance of race, sex, and class oppression as forming one struggle. Wornanism flows from a both/and worldview, a consciousness that allows for the resolution of seeming contradictions "not through an either/ or negation but through the interaction ${ }^{-}$and wholeness. Thus, while black and female may, at one level, be radically different orientations, they are at the same time united, with each "confirming the existence of the other." Rather than standing as -contradictory opposites,- they become "complementary, unsynthesized, unified wholes. ${ }^{-54}$ This is what Ogunyemi refers to as "the dynamism of wholeness. - This holistic consciousness undergirds the thinking and action of Maggie Lena Walker and the other Saint Luke women. There are no necessary contradictions between the public and domestic spheres; the community and the family; male and female; race and sex struggle - there is intersection and interdependence.

Dichotomous thinking does not just inhibit our abilities to see the lives of black women and other women of color in their wholeness, but, I would argue, it also limits our ability to see the wholeness of the lives and consciousnesses of even white middle-class women. The thinking and actions of white women, too, are shaped by their race and their class, and their consciousnesses are also formed by the totality of these factors. The failure, however, to explore the total consciousness of white women has made class, and especially race, nonexistent categories in much of white feminist theory. And this has allowed the development of frameworks which render black women's lives invisible. Explorations into the consciousnesses of black women and other women of color should, therefore, be a model for all women, including those who are not often confronted with the necessity of understanding themselves in these total terms. As we begin to confront the holistic nature of

\footnotetext{
${ }^{53}$ The essays in Vernon J. Dixon and Badi G. Foster, eds., Beyond Black or White: An Alternate America (Boston: Little, Brown, 1971) explore the either/or and the both/and worldview in relation to Africanamerican systems of analysis; the quote can be found in Dixon, "Two Approaches to Black-White Relations, ${ }^{-}$23-66, esp. 25-26.

${ }^{54}$ Johnella E. Butler explores the theoretical, methodological, and pedagogical implications of these systems of analysis in Black Studies: Pedagogy and Revolution: A Study of Afro-American Studies and the Liberal Arts Tradition through the Discipline of Afro-American Literature (Washington D.C.: University Press of America, 1981), esp. 96-102.
} 
all women's lives, we will begin to create a truly womanist studies. In our efforts Maggie Lena Walker and black women like her will be our guide.

Departments of History and Sociology State University of New York at Binghamton 